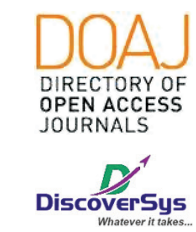

Published by DiscoverSys

\section{Gambaran umum berbagai faktor keterlambatan pemberian nutrisi enteral pada pasien anak di Ruang Rawat Intensif Anak, RSUP Sanglah, Denpasar, Bali}

\author{
Ni Luh Sri Apsari, ${ }^{1 *}$ I Gusti Lanang Sidiartha, ${ }^{2}$ I Nyoman Budi Hartawan, ${ }^{2}$ \\ Dyah Kanya Wati, ${ }^{2}$ Ida Bagus Gede Suparyatha ${ }^{2}$
}

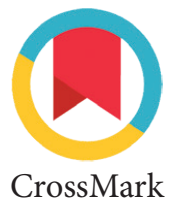

CrossMark

\section{ABSTRACT}

Background: Enteral nutrition is the primary choice in pediatric patients who do not experience gastrointestinal disorders. Many factors inhibit the achievement of enteral nutrition in pediatric patients treated in intensive care. This study aims to determine the overview of various factors that may result in delays enteral nutrition administration in critically ill pediatric patients

Methods: An observational cross-sectional analytic study was carried out on secondary data of medical records among children who were treated in pediatric intensive care unit at Sanglah Hospital throughout 2016. Delay in enteral nutrition was assessed if there was enteral nutrition administration more than $2 \times 24$ hours since first admission. Factors assessed include gender, age, PELOD, diagnosis, invasive breathing aids, impaired motility, gastrointestinal bleeding, and hemodynamic instability. Data were analyzed using the SPSS version 20 software program whereas $P$ value $<0.05$ was considered statistically significant. Results: From the 115 samples, there were $69(60 \%)$ males and $46(40 \%)$ females. About 50 samples $(43,5 \%)$ experienced delayed enteral nutrition. Significant variables related to the delay in enteral nutrition after multivariate analysis were gastrointestinal motility disorders $(p=$ 0,004, 0R 9,082, 95\% IK 2,827 - 29,171), and gastrointestinal bleeding $(p=0,0001 ; 0 R 14,317 ;$; $95 \%$ 4,087 - 50,155).

Conclusion: Intestinal motility disorders and gastrointestinal bleeding are known as a contributing factor in the delay of enteral nutrition administration in PICU Sanglah Hospital, Denpasar, Bali.

Keywords: early enteral nutrition, critically ill children, motility disturbance, gastrointestinal bleeding

Cite This Article: Apsari, N.L.S., Sidiartha, I.G.L., Hartawan, I.N.B., Wati, D.K., Suparyatha, I.B.G. 2019. Gambaran umum berbagai faktor keterlambatan pemberian nutrisi enteral pada pasien anak di Ruang Rawat Intensif Anak, RSUP Sanglah, Denpasar, Bali. Intisari Sains Medis 10(2): 313-318. D0I: 10.15562/ism.v10i2.314

Latar belakang: Nutrisi enteral adalah pilihan utama pada pasien anak-anak yang tidak mengalami kerusakan saluran cerna. Banyak faktor yang menghambat pencapaian pemberian nutrisi enteral pada pasien anak yang dirawat di ruang intensif. Penelitian ini bertujuan untuk mengetahui gambaran umum berbagai faktor yang dapat mengakibatkan keterlambatan pemberian nutrisi enteral pada pasien anak dengan penyakit kritis.

Metode: Penelitian analitik potong lintang yang berrsifat observasional dilakukan terhadap data sekunder cacatan medis anak yang dirawat di ruang rawat intensif anak RSUP Sanglah sepanjang tahun 2016. Keterlambatan nutrisi enteral dinilai apabila terdapat pemberian nutrisi enteral lebih dari $2 \times 24 j a m$ sejak pertama kali dirawat. Faktor yang dinilai meliputi jenis kelamin, usia, PELOD, diagnosis, alat bantu nafas invasif, gangguan motilitas, pendarahan saluran cerna, dan instabilitas hemodinamik. Data dianalisis menggunakan program piranti lunak SPSS versi 20 dimana nilai $\mathrm{P}<0,05$ dianggap bermakna secara statistik.

Hasil: Dari 115 sampel, terdapat 69 (60\%) anak laki-laki dan 46 (40\%) anak perempuan. Terdapat sebanyak 50 pasien $(43,5 \%)$ mengalami keterlambatan dalam pemberian nutrisi enteral. Variabel yang signifikan berhubungan dengan keterlambatan pemberian nutrisi enteral setelah dilakukan analisis multivariat adalah gangguan motilitas saluran cerna ( $p=0,004 ; 0 R$ 9,082; IK 95\% 2,827 - 29,171), dan pendarahan saluran cerna ( $p=0,0001 ; 0 R$ 14,317; IK 95\% 4,087-50,155).

Simpulan: Gangguan motilitas usus dan pendarahan saluran cerna diketahui merupakan faktor yang paling berkontribusi dalam memengaruhi keterlambatan pemberian nutrisi enteral di UPAI RSUP Sanglah, Denpasar, Bali.
IImu Kesehatan Anak, Fakultas

Kedokteran, Universitas Udayana,

Bali, Indonesia

dr.sriapsari@gmail.com

Diterima: 22-09-2018

Disetujui: 18-10-2018

Diterbitkan: 01-08-2019
Kata kunci : nutrisi enteral dini, pasien anak kritis, gangguan motilitas, perdarahan saluran cerna

Cite Pasal Ini: Apsari, N.L.S., Sidiartha, I.G.L., Hartawan, I.N.B., Wati, D.K., Suparyatha, I.B.G. 2019. Gambaran umum berbagai faktor keterlambatan pemberian nutrisi enteral pada pasien anak di Ruang Rawat Intensif Anak, RSUP Sanglah, Denpasar, Bali. Intisari Sains Medis 10(2): 313-318. DOI: 10.15562/ism.v10i2.314 


\section{PENDAHULUAN}

Pasien kritis yang dirawat di ruang intensif anak (PICU) memiliki angka morbiditas dan mortilitas yang tinggi. ${ }^{1}$ Selain dari penyakit dasar dan komplikasinya, nutrisi memegang peranan penting dalam kondisi pasien yang dirawat di PICU., ${ }^{1,2}$ Pemberian nutrisi yang baik pada anak dengan kondisi kritis dapat membantu penyembuhan. ${ }^{3}$ Pemberian nutrisi pada anak dengan penyakit kritis sangatlah penting, karena pemberian nutrisi yang tidak adekuat meningkatkan morbiditas dan berdampak buruk bagi pertumbuhan. ${ }^{4}$

Nutrisi enteral adalah pilihan utama pada pasien anak-anak yang tidak mengalami kerusakan saluran cerna, nutrisi enteral lebih mudah untuk dimulai, biaya lebih murah, dan resiko terjadinya infeksi lebih rendah. ${ }^{5}$ Beberapa penelitian menyatakan nutrisi enteral berhubungan dengan peningkatan gizi serta perbaikan klinis yang ditandai dengan penurunan mortalitas sekitar empat kali lipat. ${ }^{6}$

Pemberian nutrisi enteral dini, bertujuan untuk memenuhi kebutuhan energi dan protein serta meningkatkan angka kelangsungan hidup pasien anak di PICU. ${ }^{7}$ Pada penelitian multi senter pada 5105 pasien anak dengan penyakit kritis, 40\% mengalami keterlambatan pemberian nutrisi enteral dalam 48 jam. Pasien yang mendapat nutrisi enteral dini, memiliki dua kali lipat angka kelangsungan hidup dibandingkan yang terlambat mendapatkan nutrisi enteral. ${ }^{2}$

Beberapa literatur mengungkapkan faktor-faktor yang menjadi hambatan dalam pencapaian pemberian nutrisi enteral pada pasien PICU dibedakan berdasarkan karakteristik pasien (derajat beratnya penyakit, diagnosis, dan toleransi gastrointestinal), terapi (penggunaan penghambat neuromuskular, obat-obatan vasoaktif, ventilasi mekanik, dan prosedur lain). ${ }^{6,89}$ Berkaitan dnegan hal tersebut maka penelitian ini bertujuan untuk menentukan gambaran umum berbagai faktor yang berhubungan dengan keterlambatan pemberian nutrisi enteral pada pasien anak dengan penyakit kritis.

\section{METODE PENELITIAN}

\section{Rancangan penelitian}

Penelitian ini merupakan penelitian potong lintang dengan melihat cacatan medis pasien anak di sub-bagian ERIA terhadap 115 pasien anak yang dirawat di ruang PICU RSUP Sanglah sepanjang tahun 2016. Kriteria inklusi adalah semua pasien anak yang dirawat di ruang PICU RSUP Sanglah selama lebih dari $2 \times 24$ jam dan memiliki catatan medis yang lengkap. Pengambilan sampel ditentukan dengan menggunakan teknik consecutive sampling.

\section{Variabel penelitian}

Dilakukan analisa faktor-faktor yang mempengaruhi keterlambatan pemberian nutrisi enteral seperti usia, diagnosis saat masuk rumah sakit, derajat berat penyakit (dievaluasi dengan PELOD 2), waktu dimulainya pemberian nutrisi enteral, penggunaan ventilasi invasif, adanya gangguan motilitas usus, adanya pendarahan saluran cerna, dan hemodinamik yang tidak stabil. Definisi keterlambatan pemberian nutrisi enteral didefinisikan dengan pemberian nutrisi enteral lebih dari $2 \times 24$ jam sejak pertama kali dirawat. Rute pemberian nutrisi enteral diantaranya secara oral, selang nasogastrik, selang nasojejunal, atau via gastrostomi.

Analisis data dan Persetujuan Etik

Hasil penelitian dianlisis untuk normalitasnya telebih dahulu sebelum dilakukan analisis deskriptif. Data deskriptif ditampilkan dengan bentuk tabel sebagai jumlah (n), persentase (\%), maupun nilai median (IQR). Analisis bivariat dilakukan dengan secara uji Chi square dan analisis multivariat dilakukan dengan uji regresi logistik untuk mengetahui nilai Odds Ratio (OR) dengan tingkat kemaknaan $\mathrm{p}<0,05$. Data diproses menggunakan program Statistical Package for Social Science (SPSS) version 20. Penelitian ini telah disetujui oleh Komisi Etik Penelitian Fakultas Kedokteran Universitas Udayana/Rumah Sakit Umum Pusat Sanglah Denpasar.

\section{HASIL PENELITIAN}

Pada penelitian ini terkumpul 115 sampel dengan rekam medis yang lengkap. Terdapat 65 sampel $(56,5 \%)$ yang mendapat nutrisi enteral dini dan sisanya sebanyak 50 sampel $(43,5 \%)$ mendapat nutrisi enteral yang tertunda. Karakteristik sampel dapat dilihat pada tabel 1.

Analisa bivariat dengan uji Chi Square mendapatkan variabel dengan nilai $\mathrm{p}<0,05$ dimana menunjukkan hasil yang statistik bermakna pada skor PELOD 2, penggunaan alat bantu napas invasif, adanya instabilitas hemodinamik pada pasien, adanya gangguan motilitas usus, dan pendarahan saluran cerna. Keterlambatan pemberian nutrisi enteral terjadi pada $50 \%$ pada pasien dengan PELOD skor lebih dari 7, 64\% pada pasien yang menggunakan alat bantu napas infasig, $62 \%$ pasien dengan gangguan motilitas saluran cerna, 58\% pada pasien dengan perdarahan saluran cerna, dan $38 \%$ pada pasien dengan instabilitas hemodinamik. Hasil analisis bivariat disajikan pada Tabel 2.

Hasil analisis dilanjutkan secara multivariat dengan regresi logistik dan didapatkan skor 
Tabel 1 Karakteristik sampel penelitian terhadap berbagai faktor yang berhubungan dengan keterlambatan pemberian nutrisi enteral

\begin{tabular}{|c|c|c|c|c|c|}
\hline \multirow[b]{2}{*}{ Karakteristik } & \multicolumn{2}{|c|}{$\begin{array}{l}\text { Nutrisi enteral dini } \\
\quad(n=65)\end{array}$} & \multicolumn{2}{|c|}{$\begin{array}{l}\text { Nutrisi enteral tertunda } \\
\qquad n=\mathbf{5 0}\end{array}$} & \multirow{2}{*}{$\begin{array}{l}\text { Total } \\
\text { n (\%) }\end{array}$} \\
\hline & N (\%) & Median (IQR) & N (\%) & Median (IQR) & \\
\hline \multicolumn{6}{|l|}{ Jenis kelamin } \\
\hline Laki & $38(58,5)$ & & $31(62)$ & & $69(60)$ \\
\hline Perempuan & $27(41,5)$ & & $19(38)$ & & $46(40)$ \\
\hline Umur (bulan) & & $14(54)$ & & $12(56)$ & \\
\hline PELOD 2 & & $3(5)$ & & $7(8)$ & \\
\hline \multicolumn{6}{|l|}{ Diagnosis } \\
\hline Kardiologi & $14(21,5)$ & & $3(6)$ & & $17(14,8)$ \\
\hline Respirologi & $15(23,1)$ & & $13(26)$ & & $28(24,3)$ \\
\hline Neurologi & $15(23,1)$ & & $7(14)$ & & $22(19,1)$ \\
\hline Bedah & $8(12,3)$ & & $13(26)$ & & $21(18,3)$ \\
\hline Infeksi & $7(10,8)$ & & $6(12)$ & & $13(11,3)$ \\
\hline Lain-lain & $6(9,2)$ & & $8(16)$ & & $14(12,2)$ \\
\hline \multicolumn{6}{|c|}{ Alat bantu napas invasif } \\
\hline Ya & $18(27,7)$ & & $32(60.0)$ & & $50(43,5)$ \\
\hline Tidak & $47(72,3)$ & & $18(40.0)$ & & $65(55,7)$ \\
\hline \multicolumn{6}{|l|}{ Gangguan motilitas } \\
\hline Distensi & $3(4,6)$ & & $13(26)$ & & $16(13,9)$ \\
\hline OGT kehijauan & $4(6,1)$ & & $7(14)$ & & $11(9,5)$ \\
\hline Residu tinggi & $10(15,4)$ & & $14(28)$ & & $24(20,8)$ \\
\hline Diare & $5(4,3)$ & & $1(2)$ & & $6(5,6)$ \\
\hline Tidak & $43(95,3)$ & & $15(30)$ & & $58(50,4)$ \\
\hline \multicolumn{6}{|c|}{ Perdarahan saluran cerna } \\
\hline Perdarahan aktif & $2(1,7)$ & & $29(58)$ & & $17(14,8)$ \\
\hline Hematemesis & $0(0)$ & & $1(2)$ & & $1(0,9)$ \\
\hline Hematokezia & $3(3,1)$ & & $5(10)$ & & $8(6,9)$ \\
\hline Tidak & $60(47,8)$ & & $25(50)$ & & $80(77,4)$ \\
\hline \multicolumn{6}{|c|}{ Instabilitas hemodinamik } \\
\hline Ya & $7(26,9)$ & & $19(38)$ & & $26(22,6)$ \\
\hline Tidak & $58(65,2)$ & & $31(62)$ & & $89(77,4)$ \\
\hline
\end{tabular}

Tabel 2 Analisa bivariat keterlambatan pemberian nutrisi enteral

\begin{tabular}{lccc}
\hline Karakteristik & $\begin{array}{c}\text { Nutrisi enteral dini } \\
\text { N (\%)/Median (IQR) }\end{array}$ & $\begin{array}{c}\text { Nutrisi enteral tertunda } \\
\mathbf{N}(\%) / \text { Median (IQR) }\end{array}$ & Nilai P \\
\hline Jenis kelamin & & & \\
$\quad$ Laki & $38(58,5)$ & $32(62)$ & 0,701 \\
$\quad$ Perempuan & $27(41,5)$ & $19(38)$ & \\
$\quad$ Umur (bulan) & $14(\mathrm{IQR} 54)$ & $12(\mathrm{IQR} 56)$ & 0,598 \\
PELOD 2 & & & \\
$\geq 7$ & $17(26,2)$ & $25(50)$ & $0,007^{*}$ \\
$<7$ & $48(73,8)$ & $25(50)$ & \\
\hline
\end{tabular}


Tabel 2 Continue

\begin{tabular}{|c|c|c|c|}
\hline Karakteristik & $\begin{array}{l}\text { Nutrisi enteral dini } \\
\mathbf{N}(\%) / \text { Median (IQR) }\end{array}$ & $\begin{array}{c}\text { Nutrisi enteral tertunda } \\
\text { N (\%)/Median (IQR) }\end{array}$ & Nilai $\mathbf{P}$ \\
\hline \multicolumn{4}{|l|}{ Diagnosis } \\
\hline Bedah & $8(12,3)$ & $13(26)$ & 0,91 \\
\hline Non Bedah & $57(87,7)$ & $37(74)$ & \\
\hline \multicolumn{4}{|c|}{ Alat bantu napas invasif } \\
\hline Ya & $18(27,7)$ & $32(64)$ & $0,002^{*}$ \\
\hline Tidak & $47(72,3)$ & $18(36)$ & \\
\hline \multicolumn{4}{|c|}{ Gangguan motilitas saluran cerna } \\
\hline $\mathrm{Ya}$ & $22(33,8)$ & $31(62)$ & $0,004^{\star}$ \\
\hline Tidak & $43(66,2)$ & $19(38)$ & \\
\hline \multicolumn{4}{|c|}{ Perdarahan saluran cerna } \\
\hline Ya & $5(7,7)$ & $29(58)$ & $0,0001^{*}$ \\
\hline Tidak & $60(92,3)$ & $21(42)$ & \\
\hline \multicolumn{4}{|c|}{ Instabilitas hemodinamik } \\
\hline Ya & $7(10,8)$ & $19(38)$ & $0,0001^{\star}$ \\
\hline Tidak & $58(89,2)$ & $31(62)$ & \\
\hline
\end{tabular}

${ }^{*} \mathrm{P}<0.05$ : berbeda bermakna secara statistik

Tabel 3 Hasil analisis multivariat keterlambatan pemberian nutrisi enteral

\begin{tabular}{lccc}
\hline Variabel & Nilai-P & OR & IK 95\% \\
\hline PELOD 2 & 0,522 & 1,429 & $0,479-4,266$ \\
Alat bantu napas invasif & 0,071 & 2,278 & $0,931-5,574$ \\
Gangguan motilitas saluran cerna & 0,004 & 9,082 & $2,827-29,171$ \\
Perdarahan saluran cerna & 0,0001 & 14,317 & $4,087-50,155$ \\
Alat bantu napas invasif & 0,071 & 2,278 & $0,931-5,574$ \\
\hline
\end{tabular}

$\mathrm{OR}=$ Odds Ratio; $\mathrm{IK}=$ Interval kepercayaan; ${ }^{*} \mathrm{P}<0.05$ : berbeda bermakna secara statistik

PELOD 2, penggunaan alat bantu napas invasif, dan instabilitas hemodinamik tidak behubungan dengan keterlambatan pemberian nutrisi enteral $(\mathrm{P}>0,05)$. Gangguan motilitas saluran cerna dan pendarahan saluran cerna merupakan variabel yang signifikan berhubungan erat dengan terjadinya malnutrisi rumah sakit pada pasien anak di RSUP Sanglah (Tabel 3).

\section{PEMBAHASAN}

Anak-anak dengan sakit berat yang dirawat di PICU merupakan anak-anak dengan risiko untuk mengalami gangguan nutrisi baik dikarenakan sakit yang dideritanya ataupun dikarenakan tatalaksana nutrisi yang tidak adekuat selama perawatan. Pemberian nutrisi enteral saat ini merupakan rekomendasi pertama sebagai pilihan metode untuk pemberian nutrisi pada pasien dengan sakit berat. Nutrisi enteral banyak direkomendasikan karena merupakan metode yang paling fisiologis dan secara ekonomis lebih efisien dibandingkan metode parenteral. ${ }^{10,11}$ Nutrisi enteral diberikan baik secara oral langsung ataupun dengan menggunakan selang kedalam lambung ataupun usus halus. Berdasarkan onset pemberiannya metode nutrisi enteral terbagi menjadi metode nutrisi enteral dini jika diberikan dalam waktu kurang dari sampai dengan 48 jam, dan metode pemberian nutrisi enteral lambat jika diberikan setelah 48 jam. Pemberian nutrisi enteral juga didapatkan lebih aman dan memiliki risiko yang lebih rendah dalam terjadinya infeksi nosokomial dibandingkan pemberian secara parenteral. ${ }^{12}$

Onset atau waktu kapan pemberian nutrisi enteral diberikan sampai saat ini masih diperdebatkan, penelitian menunjukkan hasil yang berbeda-beda. Namun saat ini diyakini bahwa pemberian nutrisi enteral sedini mungkin akan memberikan luaran yang lebih baik bagi pasien dengan sakit berat. ${ }^{13,14}$ Pada studi ini didapatkan beberapa hal yang berhubungan erat dengan onset pemberian nutrisi enteral pada anak-anak yang dirawat di ruang PICU. Variabel pertama berupa 
penggunaan alat bantu napas yang bersifat invasif yaitu berupa pipa endotrakeal berhubungan dengan keterlambatan pemberian nutrisi enteral. Pasien-pasien yang menggunakan alat bantu napas invasif dengan tekanan positif dipercaya berada pada kondisi yang berisiko untuk mengalami gangguan dalam saluran cernanya. Pasien dengan ventilasi tekanan positif akan mengalami hipoperfusi pada saluran gastrointestinal. Komplikasi yang muncul berupa penurunan fungsi fisiologis dari sistem saluran cerna yang pada akhirnya keadaan ini akan mendorong terjadinya kerusakan mukosa diakibatkan stres dan hipoksia, menurunnya motilitas sistem gastrointestinal, dan terjadinya diare. ${ }^{15}$ Penelitian terdahulu mendapatkan bahwa penderita yang tetap diberikan nutrisi enteral selama perawatan dan penggunaan alat bantu napas berupa ventilator menderita pneumonia yang diyakini akibat aspirasi cairan dari lambung, dengan mortalitas yang tinggi. ${ }^{16}$ Hasil berbeda didapatkan, dimana pemberian nutrisi enteral tidak berhubungan dengan terjadinya ventilator associated pneumonia (VAP). ${ }^{17}$ Keterlambatan pemberian nutrisi enteral juga sering kali diakibatkan oleh kebiasaan atau keyakinan yang dianut dalam merawat pasien..$^{18}$ Penelitian terakhir di Kanada menunjukkan bahwa saat ini mayoritas intensifis tidak lagi menganggap bahwa penggunaan alat bantu napas dengan tekanan positif merupakan kontraindikasi pemberian nutrisi enteral. ${ }^{19}$

Gangguan atau kelainan dalam saluran cerna baik itu berupa gangguan motilitas ataupun adanya pendarahan saluran cerna berhubungan dengan keterlambatan pemberian nutrisi enteral. Adanya distensi, residu yang banyak, cairan empedu yang keluar dari pipa orogastrik, dan diare merupakan kelainan gastrointestinal. Keadaan ini akan meningkatkan risiko terjadinya aspirasi dikarenakan refluks cairan dari dalam lambung ke dalam paru-paru. Pemberian nutrisi langsung kedalam usus halus dapat mengurangi risiko terjadinya komplikasi akibat aspirasi dibandingkan dengan pemberian nutrisi enteral kedalam lambung. ${ }^{20}$ Pendarahan saluran cerna dipercaya merupakan salah satu kondisi dimana saluran cerna perlu untuk diistirahatkan. Penghentian pemberian nutrisi enteral pada keadaan ini diharapkan akan membantu pemulihan epitel saluran cerna dan mencegah kerusakan yang lebih luas akibat pemberian nutrisi enteral. Penelitian menunjukaan bahwa keadaan ini merupakan alasan utama terlambatnya pemberian nutrisi enteral. ${ }^{21}$ Hasil yang sama didapatkan pada penelitian ini dimana gangguan motilitas dan pendarahan saluran cerna merupakan faktor utama yang mengakibatkan keterlambatan pemberian nutrisi enteral pada pasien PICU.
Pasien yang dirawat diruang intensif sering kali juga didapatkan dengan keadaan hemodinamik yang tidak stabil. Hemodinamik yang tidak stabil ditandai dengan tekanan darah yang rendah dan diakhiri dengan kegagalan sistem kardiovaskuler untuk menyuplai nutrisi dan oksigen ke jaringan. Pada keadaan ini maka akan terjadi hipoksia yang berat pada tubuh termasuk pada saluran cerna. Tubuh akan berkompensasi dengan mengutamakan suplai darah kedalam organ dan jaringan-jaringan vital untuk menjaga fungsi vital tubuh. penundaan pemberian nutrisi enteral dimaksudkan untuh mencegah komplikasi yang dapat ditimbulkan karena pemberian nutrisi saat saluran cerna mengalami hipoksia. Pemberian nutrisi enteral pada pasien dengan keadaan hemodinamik yang tidak stabil sebaiknya diberikan segera setalah resusitasi. Saat kondisi pasien stabil dan tidak didapatkan adanya tanda-tanda hipoperfusi jaringan walaupun pasien dengan pemberian obat-obatan vasoaktif dan obat-obatan inotropik. ${ }^{23,24}$ Penelitian membuktikan pemberian nutrisi enteral segera setelah kondisi pasien stabil memberikan banyak keuntungan secara klinis. Pilihan rute nutrisi enteral yang diberikan yang direkomendasikan dengan menggunakan pipa nasogastrik, dengan jumlah yang sedikit. Pemberian nutrisi enteral cair yang dikenal sebagai trophic feeding dapat menjaga fungsi epitel saluran cerna sebagai pembatas untuk mencegah terjadinya translokasi bakteri. ${ }^{24}$ Pada pasien yang mendapatkan obat penopang berupa obat-obatan vasoaktif ataupun inotropik, nutrisi enteral dapat diberikan dan aman. Risiko terjadinya nonocclusive bowel necrosis (NOBN) karena pemberian nutrisi juga sangat kecil. ${ }^{25}$

Tingkat keparahan penyakit yang ditandai dengan skor PELOD 2 pada analisa bivariat didapatkan merupakan faktor yang memengaruhi keterlambatan pemberian nutrisi enteral pada pasien, namun setelah dilakukan analisa multivariat, skor PELOD 2 tidak berpengaruh signifikan terhadap keterlamatan pemberian nutrisi enteral. Pasien yang sakit berat diidentikkan dengan kondisi yang lebih parah dan tidak mampu untuk mendapatkan terapi nutrisi enteral. ${ }^{6}$

Gangguan atau kelainan dalam saluran cerna secara bivariat dan multivariat berpengaruh terhadap waktu pemberian nutrisi enteral. Pasien dengan perdarahan saluran cerna meningkatkan risiko keterlambatan pemberian nutrisi enteral sebesar 14,317 kali, sedangkan gangguan motilitas saluran cerna meningkatkan risiko keterlambatan pemberian nutrisi enteral sebesar 9,082 kali. Hasil penelitian ini konsisten dengan penelitian sebelumnya. ${ }^{1,2}$

Penelitian ini merupakan studi retrospektif sehingga memiliki beberapa kekurangan seperti ketidakmampuan untuk menunjukkan kausalitas 
dan ketidakmampuan untuk menjelaskan alasan untuk menentukan mengapa pasien tertentu diberi nutrisi enteral dini atau tidak untuk memenuhi definisi penelitian tentang nutrisi enteral dini. Kekurangan lainnya adalah adanya bias dikarenakan adanya keseragaman dalam pengambilan keputusan tentang pemberian nutrisi pada pasien di ruang perawatan PICU. Keputusan pemberian nutrisi enteral dini ataukah akan mempuasakan pasien tergantung atas keputusan dokter yang bertugas saat pasien masuk ruang PICU. Perlunya standar operasi prosedur yang mengatur pemberian nurisi bagi penderita yang akan dirawat diruang PICU saat ini sangat diperlukan, mengingat efek positif yang dapat diberikan oleh metode ini.

\section{SIMPULAN}

Penelitian ini menunjukkan bahwa terdapat beberapa faktor yang berperan terhadap keterlambatan pemberian nutrisi enteral pada anak. Faktor-faktor yang paling memengaruhi keterlambatan pemberian nutrisi enteral di ruang PICU RSUP Sanglah adalah gangguan motilitas usus, dan pendarahan saluran cerna.

\section{DAFTAR PUSTAKA}

1. Briassoulis G, Zavras N, Hatzis T. Malnutrition, Nutritional Indices, and Early Enteral Feeding in Critically Ill Children Malnutrition. Nutrition 2001; 17(7-8):548 -57.

2. Mikhailov TA, Kuhn EM, Manzi J, Christensen M, Collins M, Brown AM, Dechert R, Scanlon MC, Wakeham MK, Goday PS. Early Enteral Nutrition Is Associated With Lower Mortality in Critically Ill Children. JPEN J Parenter Enteral Nutr 2014; 38(4):459-66.

3. Mehta NM, Bechard LJ, Cahill N, Wang M, Day A, Duggan CP, Heyland DK. Nutritional practices and their relationship to clinical outcomes in critically ill children--an international multicenter cohort study. Crit Care Med. 2012; 40(7):2204-11.

4. Mehta NM, Compher C, A.S.P.E.N. Board of Directors. A.S.P.E.N. Clinical Guidelines: Nutrition Support of the Critically Ill Child. JPEN J Parenter Enteral Nutr. 2009; 33(3):260-76.

5. Mehta NM, McAleer D, Hamilton S, et al. Challenges to optimal enteral nutrition in a multidisciplinary pediatric intensive care unit. JPEN J Parenter Enteral Nutr 2010; 34(1):38-45

6. Canarie MF, Barry S, Carrol LC, Hassinger A, Kandil S, Li S, Pinto M, Valentine SL, Faustino EVS, Northeast Pediatric Critical Care Research Consortium. Risk Factors for Delayed Enteral Nutrition in Critically Ill Children. Pediatr Crit Care Med. 2015; 16(8): e283-9

7. Hamilton S, McAleer D, Ariagno K, Stenquist N, Duggan CP, Mehta NM. A stepwise enteral nutrition algorithm for critically ill children helps achieve nutrient delivery goals. Pediatr Crit Care Med. 2014; 15(7):583-9.

8. Rogers EJ, Gilbertson HR, Heine RG, Henning R. Barriers to adequate nutrition in critically ill children. Nutrition. 2003; 19(10):865-8.

9. Lee H, Koh SO, Kim H, Sohn MH, Kim KE, Kim KW. Avoidable cause of delayed enteral nutrition in critically ill children. J Korean Med Sci 2013; 28(7):1055-9.
10. Gramlich L, Kichian K, Pinilla J, Rodych NJ, Dhaliwal R, Heyland DK. Does enteral nutrition compared to parenteral nutrition result in better outcomes in critically ill adult patients? A systematic review of the literature. Nutrition. 2004; 20(10):843-8.

11. Mazuski JE. Feeding the injured intestine: enteral nutrition in the critically ill patient. Curr Opin Crit Care. 2008; 14(4):432-7.

12. Zambelan P, Delgado AF, Leone C, Feferbaum R, Okay TS. Nutrition Therapy in a Pediatric Intensive care Unit: Indication, monitoring, and complication. JPEN J Parenter Enteral Nutr 2001;35:523-9

13. Skillman HE, Mehta NM. Nutrition therapy in the critically ill child. Curr Opin Crit Care. 2012; 18(2):192-8

14. Briassoulis GC, Tsorva A, Zavras N, Hatzis T. Influence of an aggressive early enteral nutrition protocol on nitrogen balance in critically ill children. J Nutr Biochem 2002; 13(9):560

15. Mutlu GM, Mutlu EA, Factor P. Prevention and treatment of gastrointestinal complication in patient on mechanical ventilation. Am J Respir Med 2003; 2(5):395-411

16. Jacobs S, Chang RWS, Lee B, Bartlett FW. Continous enteral feeding: a major cause of pneumonia among ventilated intensive care unit patients. JPEN Parenter Enteral Nutr 1990;14(4):353-6.

17. Albert BD, Zurakowski D, Bchard LJ, Priebe GP, Duggan CP, Heyland DK. Enteral nurition and acid suppressive therapy in the pediatric intensive care unit: impact on the risk of ventilator-associated pneumonia. Pediatr Crit Care Med. 2016;17(10):924-9.

18. O’Meara D, Mireles-Cabodevila E, Frame F, Hummell C, Hammell J, Dweik RA, Arroliga AC. Evaluation of delivery of enteral nutrition in critically ill patients receivingmechanical ventilation. Am J Crit Care 2008; 17(1):53-61.

19. Leong AY, Cartwright KR, Guerra GG, et al. A Canadian survey of perceived barriers to initiation and continuation of enteral feeding in PICUs. Pediatr Crit Care Med 2014; 15(2):e49-55.

20. Heyland DK, Drover JW, Dhaliwal R, Greenwood J. Optimizing the benefits and minimizing risk of enteral nutrition in the critically ill: role of small bowel feeding. JPEN J Parenter Enteral Nutr. 2002;26(6):51-7.

21. Jacobs DG, Jacobs DO, Kudsk KA, Moore FA, Oswanski MF, Poole GV et al. Practice management guidelines for nutritional support of the trauma patient. J Trauma. 2004; 57(3):660-78

22. Chu Y, Jiang Y, Meng M, Jiang J, Zhang J, Ren H, Wang CT. Incidence and risk factors of gastrointestinal bleeding in mechanically ventilated patients. World J Emerg Med 2010;1(1):32-6.

23. Leyba OC, González JC, Alonso VC. Guide- lines for specialized nutritional and metabolic support in the critically-ill patient. Update. Consensus of the Spanish Society of Intensive Care Medicine and Coronary UnitsSpanish Society of Parenteral and Enteral Nutrition (SEMICYUC-SENPE): patient with sepsis. Med Intensiva 2011; 35(1):72-6.

24. Yang S, Wu X, Yu w, Li J. Early nutrition in critically ill patients with hemodynamic instability: an evidence-based review and practical advice. Nutr Clin Pract 2014; 29(1):90-97.

25. Wells DL. Provision of enteral nutrition durng vasopressor therapy for hemodynamic instability: an evidence-based review. Nutr Clin Pract 2012; 27(4):521-6.

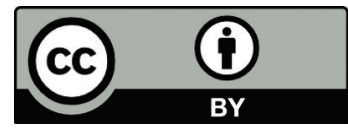

This work is licensed under a Creative Commons Attribution 